\title{
IMPLEMENTASI PENILAIAN AUTENTIK BERBASIS KURIKULUM 2013 DALAM MATA PELAJARAN PENDIDIKAN PANCASILA DAN KEWARGANEGARAAN
}

\author{
Febrian Alwan Bahrudin ${ }^{1}$, Stevany Afrizal ${ }^{2}$ \\ Universitas Sultan Ageng Tirtayasa \\ Serang, Indonesia \\ febrian.alwan@untirta.ac.id ${ }^{1}$, stevanyafrizal@untirta.ac.id ${ }^{2}$
}

\begin{abstract}
This research examines Authentic Assessment Based on Curriculum 2013 in Pancasila and Citizenship Education Subject where is located at Senior High School (SMA) Negeri 15 Pandeglang Banten. The objective of this research is to determine the implementation of authentic assessment based on curriculum 2013 in Pancasila and Citizenship Education subject which consist of cognitive, affective, and psychomotor assessments. In this research, the writer uses qualitative approach and descriptive method. The results indicate that authentic assessment in the Cognitive Aspect can be done by several types of tests: written tests, oral tests, and assignments. In the written test, there are Daily Assessment (PH), Mid-Semester Assessment (PTS), Final Semester Assessment (PAS), and also End-of-Year Assessment (PAT). Moreover, psychomotor assessments consist of performance appraisal, project appraisal, and also portofolio assessment. The Final authentic assessment based on curriculum 2013 in Pancasila and Citizenship Education Subjects is Affective assessment: observation, self-assessment, peer-to-peer assessment, and also journals. In this aspect, students are hoped to be able to implement a good personality following the values of Pancasila and the 1945 Constitution as a form of reflection of good citizen in Indonesia.
\end{abstract}

Keywords: Pancasila and Citizenship Education, Authentic Assessment, Curriculum 2013

\section{PENDAHULUAN}

Proses kegiatan belajar mengajar di kelas adalah suatu proses kegiatan yang melibatkan interaksi dua arah yaitu guru dan siswa dalam suatu mata pelajaran, yang bertujuan untuk dapat mendidik atau mentransfer ilmu dari apa yang diajarkan oleh guru terhadap diri siswa, suatu proses kegiatan belajar mengajar ini yang pada akhirnya bertujuan agar siswa mendapatkan kompetensi dari mata pelajaran yang diajarkan oleh guru di dalam proses kegiatan belajar mengajar tersebut, dalam proses kegiatan belajar mengajar yang dilaksanakan disuatu sekolah dapat menggunakan kurikulum yang berlaku, baik dengan menggunakan Kurikulum Tingkat Satuan Pendidikan atau juga dengan Kurikulum 2013, bahkan disuatu sekolah ada yang menggunakan dua kurikulum tersebut secara bersamaan dengan kelas yang berbeda, kurikulum ini sendiri merupakan sebagai suatu pedoman rancangan pendidikan untuk dapat dilaksankan dalam proses kegiatan belajar mengajar, atau juga dapat dikatakan sebagai suatu pedoman baik dalam rencana pembelajaran, tujuan pembelajaran, materi pembelajaran yang akan digunakan 
seorang guru guna untuk mencapai tujuan dari pembelajaran, hal ini juga sebagaimana terdapat dalam isi UndangUndang nomor 20 tahun 2003 pasal 1 ayat 19 yang menyebutkan bahwa kurikulum yaitu "seperangkat rencana dan sekaligus sebagai pengaturan tentang tujuan, isi, bahan pembelajaran, dan sebagai cara yang digunakan untuk dapat dijadikan sebagai pedoman penyelenggaraan kegiatan pembelajaran yang bermaksud untuk mencapai tujuan pendidikan tertentu", pendapat lain tentang kurikulum yaitu sebagaimana dikemukakan oleh Oemar Hamalik (2015:16) yang menyatakan bahwa "kurikulum merupakan sejumlah mata pelajaran disuatu sekolah yang harus dapat ditempuh dan dipelajari oleh siswa dengan tujuan untuk mendapatkan sejumlah pengetahuan”. berdasarkan kedua hal di atas dapat disimpulkan bahwa sekolah haruslah memiliki kurikulum yang sesuai, sehingga akan dapat digunakan sebagai acuan dalam proses pendidikan yang dilaksakan di sekolah tersebut, selain itu kurikulum juga dianggap sangat penting, hal ini dikarenakan kurikulum merupakan sebagai dasar dilaksanakannya pendidikan yang diimplementasikan dalam bentuk pembelajaran di kelas, dan dalam rung lingkup lebih luasnya lagi kurikulum juga dapat dimaknai sebagai acuan untuk menentukan arah pendidikan, diharapkan dengan adanya kurikulum ini arah pendidikan akan berjalan kearah yang lebih baik, berdasarkan kompetensi yang ingin dicapai, pelaksanaan kurikulum saat ini di Indonesia lebih menekankan terhadap Kurikulum 2013 sendiri dibandingkan dengan Kurikulum Tingkat Satuan Pendidikan, Kurikulum 2013 itu sendiri sebagaimana terdapat dalam Direktorat Pembinaan SMA-Direktorat Jenderal Pendidikan Menengah (2013:12) yang menyatakan bahwa "Kurikulum 2013 menekankan terhadap aspek pedagogik moderen dalam pembelajarannya, yang lebih menggunakan pendekatan ilmiah, dan di dalam pelaksanaan pembelajarannya didasarkan atas pendekatan ilmiah (scientific approach) yang lebih difokuskan terhadap terlaksananya pendekatan scientific dan juga high order thinking dalam kegiatan pembelajaran yang diindikasikan oleh keempat dimensi perluasan ilmu pengetahauan, yaitu yang pertama bagaimana memahami fakta, yang kedua bagaimana penguasaan konsep, yang ketiga bagaimana kemampuan mengembangkan prosedur penerapan konsep, dan yang terakhir bagaimana meningkatkan kesadaran tentang suatu informasi, tentang suatu proses yang telah diketahui atau juga yang belum diketahui oleh siswa", berdasarkan hal tersebut dapat diambil kesimpulan bahwa perubahan kurikulum yang terjadi dari Kurikulum 
Tingkat Satuan Pendidikan ke Kurikulum 2013 dilatar belakangi oleh perkembangan zaman kearah yang lebih moderen untuk dapat diimplemtasikan dalam proses pembelajaran dan lebih didasarkan atas pendekatan ilmiah melalui scientific dan juga high order thinking dan pada akhirnya fokus pembelajaran utamanya ada di diri siswa bukan di guru atau sebagai bentuk pendakatan pembelajaran yang berpusat di diri siswa (student centered learning) sehingga kereatifitas dalam diri siswa akan lebih berkembang kearah yang lebih baik lagi. Pendapat lain tentang pengembangan atau perubahan kurikulum dari Kurikulum Tingkat Satuan Pendidikan menuju ke perubahan Kurikulum 2013 sebagaimana dikemukan oleh Syawal Gultom (2013:1) yang menyatakan bahwa "pengembangan kurikulum yang terjadi dari Kurikulum Tingkat Satuan Pendidikan ke Kurikulum 2013 dikarenakan didalam Kurikulum Tingkat Satuan Pendidikan masih banyak ditemukan kelemahan-kelemahan yang terjadi yaitu diantaranya, muatan konten kurikulum masih terlalu banyak ditemukan matapelajaran dan materi yang keluasan dan juga tingkat dari kesukarannya melebihi dari tingkat perkembangan siswa". Berdasarkan keterangan tersebut dapat disimpulkan bahwa pengembangan yang terjadi dari Kurikulum Tingkat Satuan Pendidikan menuju perubahan ke Kurikulum 2013 dilatarbelakangi oleh masih ditemukannya kelemahankelemahan yang terjadi dalam implementasi dilapangan berkaitan dengan Kurikulum Tingkat Satuan Pendidikan.

Kurikulum Tingkat Satuan Pendidikan sendiri menurut E. Mulyasa (2006:20) yaitu menyatakan bahwa "Kurikulum Tingkat Satuan Pendidikan adalah kurikulum oprasional yang dirancang dan dilaksanakan oleh setiap satuan pendidikan, dalam rancangan Kurikulum Tingkat Satuan Pendidikan ini dilaksanakan oleh satuan pendidikan dengan memfokuskan berdasarkan standar 12 kompetensi dan kompetensi dasar yang mana telah dikembangkan oleh Badan Standar Nasional Pendidikan", lebih lanjut lagi E. Mulyasa (2006:20) menjelaskan bahwa "Kurikulum Tingkat Satuan Pendidikan dikembangkan berdasarkan satuan pendidikan, lebih menekankan terhadap potensi sekolah/daerah, lebih menekakankan terhadap karakteristik sekolah/daerah, lebih menekankan terhadap sosial budaya masyarakat dan juga karakteristik peserta didik". Berdasarkan kedua hal tersebut di atas dapat diambil kesimpulan bahwa fokus utama dari Kurikulum Tingkat Satuan Pendidikan ini lebih menekankan terhadap kompetensi dan lebih difokuskan terhadap kompetensi dasar serta lebih melihat terhadap potensi yang ada di sekitarnya, tetapi dalam pelaksanaanya fokus utama 
dalam poroses pembelajaran yang diimplementasikan di sekolah lebih menekankan terhadap pendekatan yang berbasis teacher centered learning atau lebih berfokus terhadap guru sebatas transfer ilmu terhadap diri siswa sehingga kereatifitas dalam diri siswa terbatas karena hanya fokus sebatas transfer ilmu dalam proses kegiatan belajar mengajar, selain itu Kurikulum Tingkat Satuan Pendidikan masih belum sepenuhnya menerapkan berbasis kompetensi secara menyeruruh yang sebagaimana sesuai dengan tuntunan, fungsi, serta tujuan dari pendidikan nasional itu sendiri, masih belum terakomodasinya didalam Kurikulum Tingkat Satuan Pendidikan tentang bagaimana kompetensi yang tidak sesuai dengan perkembangan kebutuhan, berdasarkan keterangan tersebut dapat ditarik suatu kesimpulan bahwa suatu perubahan kurikulum dari Kurikulum Tingkat Satuan Pendidikan menuju Kurikum 2013 yaitu dikarenakan dalam Kurikulum Tingkat Satuan Pendidikan masih ditemukan kelemahan-kelemahan dalam mengimplementasikannya diproses kegiatan belajar mengajar. dalam perubahan kurikulum ini merupakan suatu hal yang kompleks dan melibatkan semua komponen yang terkait satu sama lain yang menitik beratkan terhadap aspek sistematis dan terarah, dan diharapkan dengan adanya perubahan kurikulum ini menjadikan kualitas pendidikan di Indonesia menuju kearah yang lebih baik, karena selama ini kualaitas pendidikan di Indonesia belumlah maksimal, perubahan kurikulum tersebut menitik beratkan pada empat indikator elemen standar nasional berkaitan dengan kurikum yaitu standar kompetensi lulusan, standar isi, standar proses, dan juga setandar penilaian, dalam standar penilaian ini sendiri haruslah mengacu terhadap Peraturan Menteri Pendidikan dan Kebudayaan Republik Indonesia nomor 23 tahun 2016 tentang standar penilaian pendidikan, dalam isi peraturan tersebut lebih menekankan terhadap penilaian pembelajaran yang bersifat autentik atau komprehensif sesuai dengan sasaran kompetensi pembelajaran yang ingin dicapai secara menyeluruh baik dari berdasarkan segi kognitif, afektif, dan juga psikomotor, hal ini juga sebagaimana dikemukakan oleh Fadillah (2014:16) yang menyatakan bahwa Kurikulum 2013 merupakan "kurikulum yang dikembangkan dari Kurikulum Berbasis Kompetensi dan Kurikulum Tingkat Satuan Pendidikan yang menitik beratkan pada peningkatan dan juga keseimbangan antara soft skills dan juga hard skills, yang didalammnya terdapat kompetensi pengetahuan, kompetensi keterampilan, dan juga kompetensi sikap", dan hal ini juga berlaku dalam mata pelajaran Pendidikan Pancasila dan 
Kewarganegaraan sebagai bentuk penilaian autentik yang komprehensif atau menyeluruh. Penilaian autentik ini sendiri pada dasarnya yaitu merupakan suatu penilaian yang disesuaikan dengan semua kompetensi yang ada, hal ini sebagai mana dikemukakan oleh Kemandar (2014:31) yang menyatakan bahwa "penilaian autentik merupakan suatu penilaian terhadap peserta didik yang memfokuskan atau menekankan terhadap proses dan juga hasil dengan menggunakan berbagai instrument penilaian yang disesuaiakan dengan tuntutan kometensi yang didalamnya terdapat standar kompetensi, kompetensi inti, dan juga kompetensi dasar, penilain autentik ini sendiri berpatokan terhadap pencapaian hasil belajar yang didasarkan terhadap skor perolehan dalam hal ini yaitu skor ideal bukan dibandingkan dengan siswa lainnya, dan juga guru harus dapat melakukan penilaian melului tiga kompetensi lainnya yaitu terdiri dari kompetensi dasar, kompetensi inti dan juga standar kompetensi lulusan". Berdasarkan hal tersebut dapat diambil kesimpulan bahwa penilain autentik adalah suatu sistem penilaian yang diterapkan dalam proses pembelajaran dengan menerapakan sistem penilain secara menyeruruh baik dari segi ranah standar kompetensi, ranah kompetensi inti, dan juga ranah kompetensi dasar, yang didalamnya terdapat juga kompetensi lulusan, yang pada akhirnya merupakan hasil dari belajar atau pembelajaran yang telah dilakukan, hasil belajar ini sendiri sebagaimana dikemukan oleh Nana Sudjana (2009:22) yang menyatakan bahwa "hasil belajar atau pembelajaran terbagi atas tiga bagian yaitu yang pertama ranah kognitif, di dalam ranah kognitif ini di dalamnya terdapat segi pengetahuan, segi ingatan, segi pemahaman, segi aplikasi, segi analisis, segi sintesis, dan segi evaluasi, ranah selanjutnya yaitu afektif yang di dalamnya terdapat segi penerimaan, segi jawaban dan reaksi, segi penelitian, segi organisasi, dan juga segi internalisasi, ranah yang terkhir adalah ranah psikomotor yang di dalamnya terdapat segi gerakan reflek, segi keterampilan, segi gerakan dasar, segi kemampuan perpeptual, segi keharmonisan atau ketepatan, segi keterampilan komplek, segi gerakan ekspresif dan juga interpratatif", berdasarkan hal tersebut dapat diambil kesimpulan bahwa hasil belajar dari suatu proses pembelajaran harus melihat dari ketiga ranah, yaitu terdiri dari ranah kognitif, afektif dan juga psikomotor, dan hal ini pun berlaku dalam mata pelajaran Pendidikan Pancasila dan Kewarganegaraan, Pendidikan Pancasila dan Kewarganegaraan sendiri merupakan mata pelajaran yang mengajarakan materimateri pembelajaran yang tidak terlepas 
dari kajian keilmuan berkaitan dengan hukum, politik, sosial budaya masyarakat, yang kesemuanya bertujuan untuk menjadikan kepribadian yang sesuai dengan nilai-nilai yang terdapat dalam Pancasila dan Undang-Undang Dasar 1945, sebagai cerminan warga negara yang baik di negara Indonesia, hal ini sebagaimana terdapat dalam Peraturan Mentri Pendidikan Nasional, nomor 22 tahun 2006 yang menyatakan bahwa "Pendidikan Pancasila dan Kewarganegaraan adalah mata pelajaran yang memfokuskan terhadap pembentukan karakter warga negara yang dapat memahami dan juga melaksanakan hak dan kewajibannya untuk menjadi warga negara yang memilki kecerdasan, keterampilan, dan memiliki karakter sesuai yang damanatkan oleh Pancasila dan juga Undang-Undang Dasar 1945”, berdasarkan keterangan tersebut dapat diambil kesimpulan bahwa Pendidikan Pancasila dan Kewarganegaraan yaitu mata pelajaran yang bertujuan untuk dapat membentuk karakter warga negara yang baik berdasarkan nilai-nilai Pancasila dan Undang-Undang Dasar 1945, dalam proses kegiatan belajar mengajar mata pelajaran Pendidikan Pancasila dan Kewarganegaraan guru mengajarkan materi-materi berupa pengetahuan yang diberikan terhadap diri siswa sebagai bentuk dari ranah kogitif, dan sekaligus siswa dituntut untuk terampil dalam menerapakan keilmuannya sebagai bentuk ranah psikomotor, dan yang terakhir siswa diharapkan memiliki keperibadian yang baik sebagai bentuk ranak afektif dan kesemuanya itu dapat dievalusi secara penilaian autentik sebagai bentuk dari penerapan Kurikulum 2013 di mata pelajaran Pendidikan Pancasila dan Kewarganegaraan, tetapi dalam peraktiknya diberbagai sekolah masih ditemukan beberapa guru yang fokus evaluasi penilaiannya hanya tepaku pada ranah kognitif atau pengetahuan yang dilihat dari perolehan hasil ujian yang dijabarkan melalui nilai Kriteria Ketuntasan Minimal, tanpa melihat ranak kompetensi psikomor dan afektif sebagai bentuk evalusi yang menyeluruh atau sebagai bentuk penilaian autentik. Berdasarkan latar belakang di atas peneliti tertarik melakukan penitian yang berjudul implementasi penilaian autentik berbasis Kurikulum 2013 dalam mata pelajaran Pendidikan Pancasila dan Kewarganegaraan.

\section{METODE PENELITIAN}

Metode merapakan suatu cara atau teknik yang digunakan untuk mendapatkan atau mengumpulkan data penelitian yang diinginkan, atau dapat pula dikatakan sebagai langkah-langah yang harus dilakukan peneliti untuk dapat 
memecahkan tentang suatu permasalahan yang akhirnya mendapakan tujuan dari penelitiannya itu, hal ini sebagaimana dijelaskan oleh Sugiono (2012:5) bahwa "metode penelitian merupakan suatu cara ilmiah yang bertujuan untuk mendapatkan data yang akurat berdasarkan tujuan yang telah ditemukan, dikembangkan, dan juga dibuktikan kebenarannya tentang suatu pengetahuan sehingga dapat digunakan untuk dapat memahami, memecahkan serta mengantisipasi suatu masalah”. didalam metode ini peneliti membagi kedalam dua bagian yaitu pendekatan penelitian dan juga metode peneliatian, pendekatan penelitian yang digunakan dalam penelitian ini yaitu menggunakan pendekatan penelitian secara kualitatif, dimana pendekatan penelitian secara kualitatif ini merupakan suatu jenis penelitian yang bertujuan untuk dapat memahami fenomena tentang suatu hal yang dilamai oleh subjek penelitian ini sendiri, hal ini sebagaimana dikemukakan oleh Meleong (2007:4) yang menyatakan bahwa pendekatan penelitian secara kulitatif yaitu "penelitian yang memiliki prosedur untuk dapat menghasilkan data secara deskriptif yaitu berupa suatu kalimat atau kata-kata atau juga secara lisan berdasarkan prilaku seseorang yang telah diamati dari suatu fenomena yang terjadi", sedangkan metode yang digunakan dalam penelitian ini adalah dengan menggunakan metode deskripstif, metode deskriptif ini sendiri yaitu suatu metode penelitian yang bertujuan untuk menggambarkan atau menjelaskan tentang suatu fenomena yang sedang terjadi, hal ini sebagaimana dikemukan oleh Arikunto (2010:3) yang meyatakan bahwa "metode penelitian dengan menggunakan deskriftif merupakan suatu jenis penelitian yang bertujuan untuk dapat menyelidiki suatu kadaan, kondisi atau hal-hal lainnya, yang mana akhirnya akan dipaparkan dalam bentuk laporan penelitian, dengan tidak mengubah data, menambahkan data, atau juga menggandakan memanipulasi terhadap suatu objek atau tempat penelitian, peneliti hanya menggambarkan tentang apa yang terjadi berdasarkan subjek dan objek penelitian yang mana pada akhirnya dipaparkan dalam bentuk penelitian secara jelas sesuai dengan apa adanya berdasarkan hasil dari penelitian yang dilakukan", selain menggunakan metode penelitian dalam penelitian ini juga menjelaskan berkiatan dengan objek dan subjek penelitian, objek penelitian itu sendiri adalah suatu hal yang berkaitan dengan variabel penelitian dan juga berkaitan dengan masalah yang diteliti, hal ini sebagaimana dikemuka oleh Arikunto (2005:29) yang menyatakan bahwa "objek penelitian yaitu variabel penelitian yang merupakan sesuatu inti dari problematika penelitian". Subjek penelitian yaitu suatu 
hal yang berkaitan dengan penelitian seperti benda, orang, tempat, yang berkaitan dengan penelitian, hal ini sebagaimana dikemukan oleh Arikunto (2005:29) yang menyatakan bahwa "subjek penelitian yaitu adalah benda, hal, orang, tempat yang berkaitan dengan data variabel penelitian", berdasarkan penjelasan objek dan subjek penelitian di atas maka objek penelitian yang peneliti lakukan yaitu tentang implementasi penilaian autentik berbasis kurikulum 2013 dalam mata pelajaran Pendidikan Pancasila dan Kewarganegaraan, sedangkan berkaitan dengan subjek penelitiannya yaitu guru dan siswa di sekolah menengah atas, selanjutnya peneliti menyusun instrument, instrument ini sendiri yaitu suatu alat yang digunakan peneliti untuk dapat mengumpulkan data penelitian, adapun instrument yang peneliti gunakan dalam penelitian ini yaitu menggunakan teknik observasi, teknik wawancara, dan juga dokumentasi sebagai bentuk dari tri angulasi data, tri angulasi data sendiri yaitu merupakan suatu cara untuk mendapatkan keabsahan data dengan menggunakan pendekatan secara kualitatif, hal ini sebagaimana dikemukan oleh Moleong (2011:330) yang menyatakan bahwa "triangulasi merupakan suatu teknik atau cara untuk dapat memeriksa keabsahan data yang berkaitan dengan memanfaatkan sesuatu yang lain untuk dapat mengecek dan membandingkan data satu sama lain", dalam hal ini peneliti langsung melakukan penelitian ke tempat penelitaian atau ke lapangan sebagai bentuk dari field research atau penelitian lapangan, penelitian lapangan itu sendiri adalah suatu jenis penelitian yang bertujuan untuk mendapatkan data primer yaitu melalui observasi, wawancara, dan juga dokumentasi sebagai dari triangulasi teknik penelitian, observasi yaitu suatu kegiatan pengematan penelitian yang bertujuan untuk mengumpulkan data penelitian hal ini sebagaimana dikemukan oleh sugiyono (2015:204) yang menyatakan bahwa "Observasi adalah suatu kegiatan pengamatan penelitian terhadap suatu kajian objek penelitian, dan dalam proses pelaksanaan observasi bertujuan untuk mengumpulkan data dibagi menjadi dua katagori yaitu partisipan dan non partisipan”. Observasi yang peneliti lakukan yaitu tentang implementasi penilaian autentik berbasis kurikulum 2013 dalam mata pelajaran Pendidikan Pancasila dan Kewarganegaraan. Wawancara adalah suatu teknik pengumpulan data yang digunakan peneliti dengan tujuan mendapatkan informasi dari nara sumber penelitian, pengunaan teknik wawancara dalam penelitian ini yaitu dengan mengunakan wawancara secara bebas 
terpimpin, wawancara bebas terpimpin ini sendiri yaitu merupakan teknik wawancara yang dilakukan oleh peneliti secara bebas tetapi masih pada koridor atau pedoman wawancara yang telah dibuat peneliti, hal ini sebagaimana dikemukan oleh Arikunto (2013:199) yang menyatakan bahwa "wawancara bebas terpimpin adalah suatu teknik wawancara yang dilakukan peneliti dengan mengajukan pertanyaanpertanyaan penelitian secara bebas tetapi tetap berada dipedoman wawancara yang telah dibuat", dalam hal ini wawancara yang peneliti lakukan yaitu terhadap guru mata pelajaran Pendidikan Pancasila dan Kewarganegaraan dan juga siswa di sekolah tempat peneliti melakaukan penelitian. Dokumentasi merupakan suatu cara yang digunakan untuk memperoleh data dari sumber, baik berupa foto, buku, atau arsip lainnya yang menunjang terhadap data penelitian, hal ini sebagaimana dikemukan oleh Sugiono (2015:329) yang menyatakan bahwa dokumentasi adalah "suatu cara yang digunakan untuk dapat memperoleh data dan informasi baik dalam bentuk buku, arsip, dokumen, tulisan, angka atau juga gambar yang berupa data untuk dapat mendukung data penelitian" berdasarkan hal tersebut dukumentasi pendukung dalam penelitian ini yaitu diantaranya berupa foto kegiatan belajar mengajar, dan juga proses penilaian autentik yang dilakukan oleh guru mata pelajaran Pendidikan Pancasila dan Kewarganegaraan, dan juga dokumendokumen lainnya yang mendukung terhadap data penelitian, setelah data penelitian didapatkan maka langkah selanjutnya yang peneliti lakukan yaitu melalui analisis data, teknik analisis data sendiri sebgaimana dikemukan oleh Moleong (2011:248) yang menyatakan bahwa "suatu upaya yang dilakukan dengan jalan berkerja dengan data penelitian, mengorganisasikan data penelitian, memilah data untuk dapat dikelola, mensintesiskan data, mencari dan menemukan pola data, menemukan data yang penting serta apa yang dipelajari, dan memutuskan data apa yang dapat diceritakan atau deskripsikan”. Berdasarkan hal tersebut maka data yang peneliti analisis dalam penelitian kualitatif ini yaitu terdiri dari pengumpulan data penelitian, reduksi data penelitian, penyajian data penelitian, dan penarikan kesimpulan penelitian.

\section{HASIL PENELITIAN DAN PEMBAHASAN HASIL PENELITIAN}

Pembelajaran Pendidikan Pancasila dan Kewarganegaraan memilki tiga tahapan yang diawali dari tahap perencaaan, tahap pelaksaan dan tahap evalusasi, setiap tahapan tersebut harus dapat dilaksanakan dengan baik dan benar, 
hal ini dikarenakan ketika ditahap awal perencaan pembelajaran terdapat kesalahan maka tahap selanjutnya seperti tahap pelaksaaan dan evaluasi akan terjadi kesalahan, maka dasar utamanya terdapat pada tahap perencaan itu sendiri, tahap selanjutnya yaitu tahap pelaksanaan pembelajaran, dalam tahap ini terbagi atas tiga kegiatan pembelajaran, yaitu terdiri dari kegiatan pendahuluan, kegiatan inti, dan kegiatan penutup, dalam kegiatan pendahuluan di dalamnya terdapat langkah-langkah yang harus dapat dilaksanakan oleh guru dan siswa itu sendiri, begitu juga dengan kegiatan inti dan penutup terdapat langkah-langkah di dalamnya yang harus dilaksanakan. dan yang terakhir yaitu adalah tahap evaluasi sebagai bagaian dari penilaian pembelajaran yang telah dilaksanakan dan hal ini berlaku juga dalam mata pelajaran Pendidikan Pancasila dan Kewarganegaraan, penilaian yang dilakukan di mata pelajaran Pendidikan Pancasila dan Kewarganegaraan yaitu dengan menggunakan penilaian secara menyeluruh sebagai bentuk dari penilaian autentik yang bersifat objektif komprehensif. Penilaian autentik ini adalah jenis penilaian yang dilakukan guru terhadap diri siswa berdasarkan hasil proses pembelajaran yang telah dilaksakan dengan mengukur ranah pengetahuan (kognitif), afektif (sikap) dan psiskomotor (keterampilan), penilaian autentik yang dilaksanakan dalam mata pelajaran Pendidikan Pancasila dan Kewarganegaraan ini sendiri terdiri dari tiga penilaian yaitu terdiri dari:

\section{Penilaian Pengetahuan (Kognitif)}

Penilaian pengetahuan ini merupakan suatu penilaian yang mengarah pada ranah kognitif dimana unsur utamanya dalam penilaian ini yaitu tentang pengetahuan siswa berdasarkan hasil dari proses pembelajaran, penilaian pengetahuan yang dilakukan di kurikulum 2013 ini didasarkan atas ranah pengetahuan baik secara faktual, konseptual, prosedural, metakognitif, dan juga menekankan daya berfikir siswa dari yang tingkat bawah sampai dengan tingkat tinggi, dalam penilaian pengetahuan ini dapat dilakukan dengan beberapa jenis tes untuk mengukur pengetahuan siswa yaitu diantaranya melalui tes tulis, tes lisan, dan penugasan. Tes tulis murupakan suatu jenis tes yang mengharuskan siswa menjawab pertanyaan-pertanyaan secara tertulis yang dibuat oleh guru dan harus dijawab secara tertulis oleh siswa, dalam tes tulis ini guru dapat melaksanakannya seperti membuat soal Penilaian Harian (PH), Penilaian Tengah Semester (PTS), Penilaian Akhir Semester (PAS), dan juga Penilaian Akhir Tahun (PAT) secara tertulis baik melalui tes uraian ataupun tes pilihan ganda, soal-soal yang guru buat 
tersebut haruslah mengacu pada materi yang telah diajarkan dalam proses pembelajaran yang didasarkan sebagaimana yang terdapat dalam Silabus dan Rencana Pelaksanaan Pembelajaran (RPP) yang telah dibuat dalam perencanaan pembelajaran itu sendiri seperti setiap butih soal pertanyaan tes tulis harus mengacu pada rumusan indikator sasaran kompetensi dari materi mata pelajaran Pendidikan Pancasila dan Kewarganegaraan. Implentasi penilaian pengetahuan tes tulis ini sendiri terdapat kelebihan yaitu diantaranya guru akan lebih mudah untuk mempersiapkan soal tes untuk diujikan terhadap diri siswa sehingga jawaban siswa akan lebih objektif terlihat di kertas lembar jawaban, jawaban yang diberikan siswa akan lebih kereatif untuk menyusun kalimat di lembar jawaban sesuai dengan gaya bahasa masing-masing individu siswa, selain memiliki kelibihan tes tulis juga memilki kelemahan yaitu diantaranya, guru memerlukan waktu lebih lama untuk mengkoreksi lembar jawaban setiap siswa, selaian itu juga terdapat kalimat-kalimat jawaban yang dapat ditapsirkan sedikit subjektif berdasarkan analisan guru atas jawaban yang dituliskan siswa. Berdasarkan hal tersebut pelaksanaan tes tulis ini merupakan salah satu jenis tes yang disukai siswa karena jenis tes ini menurut siswa merupakan jenis tes yang tidak begitu membuat diri siswa merasa tegang untuk mengerjakan soal atau menjawab pertanyaan-pertanyaan, dan siswa akan lebih memilki menejemen waktu untuk mengerjakan soal sesuai dengan durasi waktu yang telah tertera dalam lembar pertanyaan atau lembar soal yang dibuat oleh guru.

Jenis tes selanjutnya yang dapat digunakan guru dalam penilaian autentik ini sendiri yaitu melalui jenis tes lisan, jenis tes ini yaitu guru dapat secara langsung memberikan pertanyaan melalui ucapan tentang pertanyaan-pertanyaan untuk dapat menguji pengetahuan siswa dalam hal mengetahui atau memahami suatu kompetensi pengetahuan dari hasil proses pembelajaran, dalam pelaksanaan jenis tes lisan ini memilki kelebihan yaitu diantaranya, guru dapat mengetahui secara langsung jawaban atas pertanyaanpertanyaan dan sekaligus dapat mengetahui secara langsung tingkat kompetensi siswa, guru dapat mengefesiensikan waktu untuk mengoreksi dan sekaligus memberikan penilaian terhadap diri siswa, dan selaian itu juga dapat meminimalisir jawaban spekulitif yang diutarakan diri siswa, selaian memilki kelebihan dalam pelaksanaan tes lisan ini juga memilki kekurangankekurangan dalam pelaksanaaanya yaitu diantaranya tingkat konsentarasi diri siswa diperlukan lebih konsen dan siswa 
cenderung lebih tegang karena langsung berhadapan dengan guru yang mengetaskan tes lisan ini, guru memerlukan durasi waktu yang lama dalam mengetes setiap individu siswa itu sendiri karena dalam tes ini terdapat dua teknik pertanyaan untuk menguji ranah kognitif siswa yaitu bisa dilaksakan tes lisan secara pupulasi yaitu guru memberikan pertanyaan di depan seluruh siswa untuk siapa yang bisa menjawab pertanyaan tersebut atau dengan teknik individu yaitu guru memberikan pertanyaan untuk setiap individu siswa dan yang memerlukan durasi waktu yang lebih lama, pada tahap implementasi tes lisan ini siswa cenderung kurang menyukai hal ini dikarenakan dalam pelaksnaan tesnya siswa merasa tanggang karena berhadapan langsung dengan guru yang memberikan pertanyaan, pelaksanaan tes lisan dalam mata pelajaran Pendidikan Pancasila dan Kewarganegaraan ini guru membuat soal yang harus disesuaikan dengan memperhatikan analisis kompetensi dasar, membuat atau menyusun kisi-kisi pertanyaan soal yang disesuaikan dengan kompetensi dasar, membuat pertanyaan atau soal yang sesuai dengan petunjuk dimaksudkan untuk memudahkan siswa menjawab pertanyaan secara lisan, guru harus dapat menyusun pedoman penilaian untuk dapat mengukur ranah kognitif siswa, dan yang terakhir yaitu guru memberikan tindak lanjut berdasarkan hasil tes yang telah dilakukan, selain menggunakan kedua jenis tes untuk mengukur kemampuan diri siswa dalam hal kompetensi pengetahuan jenis tes selanjutnya yaitu menggunakan jenis tes penugasan, dimana jenis tes ini merupakan suatu jenis tes baik secara langsung maupun tidak lansung seperti penugasan untuk mengerjakan pekerjaan rumah atau PR yang dapat dilaksakan ketika proses pembelajaran di kelas telah dilaksanakan, atau juga dapat dilakukan dengan cara penugasan di dalam kelas yaitu seperti guru memberikan tugas untuk mendiskusikan tetang suatu kajian yang disesuaikan dengan pembahasan materi mata pelajaran Pendidikan Pancasila dan Kewarganegaraan, jenis tes penugasan ini dapat dilakukan melalui penugasan secara individu ataupun kelompok, dan tentunya penugasan yang diberikan guru tersebut harus dapat mengukur setiap sasaran kompetensi dari materi yang diajarkan. Dalam jenis tes penugasan ini memilki kelebihan dalam implementasinya yaitu diantaranya dapat melatih karakter tanggung jawab dan disiplin siswa untuk dapat menyelesaikan tes penugasan yang diberikan oleh guru, selain memiliki kelebihan dalam tes peneguasan ini juga terdapat keleman terutama dalam tes penugasan diluar jam pelajaran atau penugasan di rumah (PR) masih terdapat 
beberapa siswa yang belum melaksanakan tes penugasan yang diberikan oleh guru dengan alasan yang bermacam-macam sehingga tugas yang diberikan oleh guru terbengkalai, dengan adanya jenis tes penugasan ini diharapkan siswa akan lebih banyak menggunakan waktu luangnya untuk digunakan belajar.

Berdasarkan hal-hal tersebut di atas yang menjelaskan tentang penilaian autentik dari segi kompetensi kognitif atau pengetahuan itu sendiri maka dapat diambil kesimpulan bahwa ranah kognitif ini memfokuskan terhadap kemampuan pengetahuan diri siswa berdasarkan materi yang telah diajarkan oleh guru terhadap diri siswa. Dalam hal ini setiap kemampuan pengetahuan diri siswa berbeda-beda dalam mengingat atau memahami materi yang telah diajarkan oleh guru itu sendiri, maka guru diharapkan untuk tidak menyamaratakan kemampuan pengetahuan yang dimiliki siswa, dan guru harus memberikan perhatian khusus terhadap siswa yang tertinggal dalam hal memahami meterimateri yang telah diajarakan, sehingga diaharapkan setiap diri siswa atau individu siswa dapat memahami meteri secara menyluruh, tidak ada yang tertinggal antara satu indivdu dengan individu yang lainnya, dan diharapkan dengan adanya penilianan pengetahuan ini melalui jenis tes tuliis, lisan dan penugasan dapat meningkatkan dan sekaligus mengukur tingkat kemampun pengetahuan atau konitif di dalam diri siswa yaitu lebih mengetahui dan memahami kompetensi pengetahuan siswa berdasarkan materimateri yang telah diajarakan, selain itu penilaian pengetahuan ini didasarkan dari bagaimana siswa dapat meneyelesaikan ketuntasan belajar, dan juga dapat mengidentifikasi kelebihan dan kelemahan dalam mengetahuai tentang kemampuan kognitif siswa berdasarka hasil tes yang dilakukan guru terhadap ranah kognitif di dalam diri siswa.

\section{Penilaian \\ Keterampilan (Psikomotor)}

Pada tahap penilaian keterampilan ini merupakan tahapan lain untuk menguji kompetensi psikomotor siswa, dalam tahap ini yang menjadi unsur penilaian utama yaitu bagaimana daya kereatifitas dan daya keritis siswa yang ditampilkan. Indikatorindikator yang terdapat dalam penilaian keterampilan secara autentik dalam mata pelajaran Pendidikan Pancasila dan Kewarganegaraan yaitu diantaranya penilaian kinerja, penilain proyek, dan juga penilaian prtofolio.

Penilaian kinarja merupakan suatu jenis penilain yang dilakukan oleh guru terhadap siswa berdasarkan hasil kinerja yang ditugaskan oleh guru, dalam mata pelajaran Pendidikan Pancasila dan Kewarganegaraan ini penilain kinerja yang 
biasa dilakukan yaitu seperti diskusi kelompok, berdasarkan penilaian kinerja melalui diskusi kelompok tersebut guru berperan sebagai observer untuk mengamati kenirja masing-masing individunya disetiap kelompoknya, dan guru dapat melakukan penilaian berdasarkan hasil observasi yang telah guru lakukan pengamatan terhadap diskusi tersebut. Dalam penilain kinerja ini terdapat kekuarangan dan kelibahan, yaitu diantanranya, kekurangan dari penilaian kinerja masih terdapat beberapa kelompok yang didominasi oleh seseorang dalam kelompoknya, sedangkan kelebihannya dalam setiap kelompok terdapat mentor yang dianggap memilki kelebihan kemampuan untuk dapat memimpin jalannya diskusi dan memberikan kesempatan untuk semua individu menyampaikan pendapatnya di diskusi kelompoknya tersebut. Penilaian selanjutnya yaitu penilaian proyek, penilaian ini merupakan jenis tugas yang diberikan oleh guru terhadap diri siswa dengan durasi waktu yang telah ditentukan, dalam penilaian proyek ini didalamnya terdapat indikator-indikator tahapan yang harus diperhatikan diantaranya dimulai dari perencanaan, pengumpulan data, pengorganisasian, pengolahan, analisis, sampai dengan tahap penyajian data, dalam penilain ini diperlukan kemapuan pemahaman, kemampuan analitis dan juga keritis agar dapat disajikan dalam laporan proyek ini, penilai proyek ini dapat dilaporkan dalam bentuk laporan tertulis atau juga laporan seperti poster, pelaksanan penilai proyek ini yang biasa digunakan di pembelajaran Pendidikan Pancasila dan Kewarganegaraan yaitu biasnya mengunakan pembagian kelompok, dan setiap kelompok terdiri dari ketua dan anggota yang rata-rata setiap kelompoknya terdiri dari 4 atau lima orang, hal ini dimaksudkan agar melatih siswa untuk dapat berkerja sebagai tim dalam kelompoknya masing-masing dan sekaligus mengajarkan saling menghargai ide atau gagasan disetiap anggota kelompoknya sehingga semua anggota memilki porsi masing-masing dalam menyampaikan gagasan atau ide dalam melaksanakan penilaian proyek ini, pelaksanaann penilaian proyek ini memiliki kekurangan yaitu diantaranya masih ditemuakan dibeberapa kelompok yang cenderung didominasi oleh orangorang tertentu dalam mengerjakan penilai proyek ini, selaian memilki kekurang dalam penilai proyek ini memilki kelebihan yaitu salah satunya guru dapat memberikan kebebasan dalam menuangkan pemikiran atau gagasan yang dimiliki dalam bentuk laporan, sehingga keretivitas diri siswa lebih dapat dimaksimalkan, dan hal ini pun sesuai 
dengan jenis pendekatan pembelajaran

Pendidikan

Pancasila

dan

Kewaarganegaraan yang berbasis student centered learning sebagai bentuk dari pembelajaran yang berpusat pada diri siswa.

Penilaian selainjutnya yaitu penilai jenis portofolio, penilaian portofolio ini adalah suatu jenis penilaian yang dilakukan guru terhadap hasil karya siswa, hasil karya yang dihasilkan ini hasil pengamatan atau penelitian siswa berdasarkan judul pengamatan atau penelitian yang siswa lakukakan, dalam membuat tugas portofolio ini memilki langkah-langkah yaitu dimulia, dari mengidentifikasi masalah, memilih kajian masalah, mengumpulkan informasi data, mengembangkan bahan portofolio kelas, menyajikan portofolio, dan yang terakhir yaitu mereflesikan pengalaman belajar. Penilain portofolio yang biasa digunakan dalam pembelajaran Pendidikan Pancasila dan Kewarganegaraan ini dikenal juga dengan project citizen, penggunaan project citizen ini dianggap salah satu metode pembelajaran yang disukai oleh siswa karena proses pembelajaran dianggap menyenangkan, project citizen menggunakan beberapa penggabungan model-model pembelajaran yaitu diantaranya problem solving (pemecahan masalah), sosial inquiry (penelitian sosial), sosial involvement (perlibatan sosial), covarative learning (belajar bersama), simulated hearing (simulasi dengan pendapat), deep dialogue and critical thinking (dialog mendalam dan berfikir kritis), value clarification (klarifikasi nilai) dan juga democrating teaching (pembelajaran demokrasi). Berdasarkan indikator-indikator penggabungan modelmodel pembelajaran dalam project citizen tersebut diharapkan dapat memaksimalkan sasaran kompetensi pembelajaran di dalam diri siswa, hal ini dikarenakan dengan mengunakan project citizen depat meghasilkan powerfull learning atau dapat dikatakan menghasilkan pembelajaran yang berkualitas dengan mengedepankan kebermaknaan pembelajaran, keterpaduan pembelajaran, pembelajaran mengedepankan berbasis nilai, pembelajaran yang menantang, pembelajaran yang menbuat siswa aktif, dan pembelajaran yang menyenangkan dalam pelaksanaannya. Kekurangan dalam implementasi dari penilaian portofolio ini atau dalam mata pelajaran Pendidikan Pancasila dan Kewarganegraan yang biasa digunakan yaitu menggunkan project citizen, dalam implemementasinya yaitu masih belum meratanya tanggung jawab dari setiap individu kelompok atau masih masih ditemukan individu yang cenderung mendominasi untuk mengerjakan project citizen ini, sedangkan jenis penilain ini merupakan suatu jenis 
penilaian kelompok bukanlah individu yang hanya mengandalkan individu tertentu. Untuk kelebihannya sendiri dalam project citizen ini yaitu merupakan suatu jenis tes yang dapat membuat lebih trampil dan berfikir keritis siswa lebih menigkat kearah yang lebih baik kerana dalam pelaksanaanya merupakan suatu jenis tes yang depat meghasilkan powerfull learning dari berbagai macam modelmodel pembelajaran.

\section{Penilai Sikap (Afektif)}

Penilai sikap dalam pembelajaran Pendidikan Pancasila dan Kewarganegaraan merupakan langkah terakhir setelah penilai sebelumnya yaitu penilai pengetahuan dan juga penilain keterampilan, yang menjadi indikator dalam penilai sikap ini diharapkan siswa dapat mengimplementasikan kepribadian yang baik yang sesuai dengan nilai-nilai Pancasila dan Undang-Undang Dasar 1945 sebagai bentuk cerminan warga negara yang baik di Indonesia, penilai sikap ini memiliki beberapa cara untuk diterapkannya yaitu diantaranya dengan cara observasi, penilaian diri, penilain antar teman, dan juga jurnal.

Penilaian pertama yaitu penilaian guru, peneilaian guru disini dengan menggunakan teknik observasi, observasi merupakan termasuk kedalam teknik penilaian utama dalam penilaian sikap, observasi ini dibagi atas dua bagian yaitu penilaian yang dilakukan oleh wali kelas dan juga dapat dilakukan oleh guru bimbingan konseling, dan yang berkaitan dengan mata pelajaran penilaian observasi dilakukan oleh guru mata pelajaran, kesemua penilaian tersebut dilakukan selama satu semester, untuk proses penelilaian guru terhadap diri siswa dengan teknik observasi dapat dilakukan selama proses pembelajaran di dalam kelas ataupun di luar pembelajaran kelas. Penilai sikap ini dapat dilakukan dengan guru membuat jurnal ataupun instrumen penilai sikap, dalam kurikulum 2013 penilaian sikap dibagi atas dua indikator yaitu penilain sikap spiritual yang berkaitan dengan nilai-nalai keagamaan, dan penilain sikap sosial yang berkaiatan dengan interaksi sosial, selain hal tersebut penilaian sikap dengan teknik observasi ini tidak terlepas dari unsur yang harus diamati oleh guru mata pelajaran selaku observer yaitu mengamati sikap siswa yang disesuaikan dengan pencapain sasaran kompetensi dalam hal ini yaitu kompetensi dasar (KD), dan akan lebih fokus diamati disesuaikan dengan ranah kompetensi inti 1 (KI-1), ranah kompetensi inti 2 (KI-2) dan seterusnya.

Penilaian diri merupakan salah satu jenis penilaian yang dilakukan oleh individu siswa sendiri sebagai betuk dari refleksi diri dan sekaligus untuk dijadikan evaluasi diri individu setiap siswa, dalam 
penilain diri ini setiap siswa diajarkan untuk bersikap jujur untuk dapat menilai diri sendiri dan diharapkan dapat memperbaiki diri berdasarkan evaluasi diri yang telah dilakukan, penilain diri yang biasanya sering digunakan yaitu dengan mengunakan istrumen tertutup hal ini dimaksudkan agar lebih mudah untuk mengevaluasi tindak lanjut dari hasil evaluasi diri tersebut, dibandingkan dengan jenis instrumen evalusi diri yang terbuka, karena akan memberikan kesempatan untuk argumentasi ataupun jawaban atas pertanyaan evaluasi diri tersebut.

Penilaian selanjunya yaitu penilaian antar teman, dalam penilaian ini melibatkan teman, dapat dikatakan sebagai tindak lanjut dari penilain diri terkait dengan sikap atau kepribadian siswa dan dinilai oleh siswa laiannya, instrumen yang digunakan dalam penilai diri ini memiliki kemiripan dengan penilaian diri yaitu dapat digunakan dengan jenis instrument tertutup dan terbuka, begitu juga dengan penilain antar teman ini sebaiknya menggunakan jenis instrumen penilai tertutup untuk menghindari alasanalasan subjektif dari jawaban pertanyaan yang tertera di instrument, penialain antar teman dapat dijadikan untuk mencocokan antara hasil penilain diri dengan penilaian antar teman sehingga diharapkan akan mendapatkan data evalusi yang objektif untuk dijadikan data penilaian. Berdarakan hal tersebut hasil dari penilain antar teman dapat digunakan guru untuk menindak lanjuti hasil yang kurang baik dalam diri siswa untuk dapat meningkatkan kepribadian siswa kearah yang lebih baik lagi.

Penilaian terakhir dalam ranah afektif yaitu penilai jurnal, penilaiai jurnal merupakan subuah catatan dari guru terhadap hasil evalusi diri siswa yang berkaitan dengan sikap atau karakter siswa baik yang bersifat positif dan juga negatif dalam ruang lingkup kegiatan pembelajaran atau di luar proses pembelajaran, dengan adanya penilaian jurnal ini guru akan lebih mudah mendokumentasikan hasil analisis berkaitan data kepribadian siswa untuk dijadikan tindak lanjut perbaikan keperibadian yang lebih baik terhadap diri siswa.

\section{SIMPULAN}

Berdasarkan hasil pembahasan di atas dapat diambil kesimpulan bahwa implementasi penilaian autentik dalam mata pelajaran Pendidikan Pancasila dan Kewarganegaraan haruslah dilaksanakan secara komprehensif sebagai bentuk penialain autentik tersebut, mulai dari penilaian ranah pengetahuan (kognitif), penilaian ranah keterampilan (psikomotor), juga ranah kepribadian (afektif) dan kesemuanya haruslah dievaluasi secara 
menyeluruh sehingga semua kompetensi dapat dinilai secara keseluruhan.

Ranah kognitif atau pengetahuan menjadi ranah pertama dalam penilaian, dalam ranah ini siswa dievalusi tinggkat pengetahuannya dengan beberapa cara yaitu melalui tes tulis, tes lisan, dan penugasan, implementasi dari kesemua tes tersebut sudah dilaksanakan dengan baik, walaupun dalam pelaksanaanya masih ditemukan sedikit kekurangan-kekurangan yang harus dapat ditingkatkan lebih baik lagi. Ranah selanjutnya yaitu penilaian psikomotor atau keterampilan dalam implementasi dipenilaian psikomotor ini terdapat beberapa cara yaitu diantaranya penilaian kinerja, penilain proyek, dan juga penilaian portofolio, dalam ranah ini penilaian yang paling sering digunakan dalam mata pelajaran Pendidikan Pancasila dan Kewarganegaraan yaitu dengan menggunakan project citizen sebagai bagian dari peniaian portofolio, dengan mengunakan project citizen depat meghasilkan powerfull learning atau dapat dikatakan menghasilkan pembelajaran yang berkualitas dengan mengedepankan kebermaknaan pembelajaran. Dan yang terakhir yaitu ranah afektif, dalam ranah ini diharapkan siswa dapat mengimplementasikan kepribadia yang baik yang sebagaimana nilai-nilai Pancasila dan juga Undang-Undang Dasar 1945 sebagai bentuk cerminan warga negara yang baik di Indonesia, penilai sikap ini memiliki beberapa cara untuk diterapkannya yaitu diantaranya dengan observasi, penilaian diri, penilain antar teman, dan juga jurnal. Dalam implementasinya setiap cara penilaian sikap ini yang paling dominan dilakukan yaitu penilai observasi dalam hal ini guru berperan sebagai observer yang menilai keperibadian siswa dengan instrument yang telah dipersiapakan dan dengan teknik obsevasi ini sampai sejauh ini sangat memiliki pengaruh yang cukup besar untuk dijadikan bahan evaluasi kepribadian lebih baik lagi. Semua tahap penilain yang dilakukan sebagai bentuk dari penilaian autentik ini dilakukan untuk dijadikan bahan evaluasi yang komprehensif, dan objektif dalam penilaian.

\section{DAFTAR PUTAKA}

Arikunto, Suharsimi.

(2005). ManajemenPenelitian. Jakarta; Rineka Cipta.

Arikunto, Suharsimi. (2010). Prosedur Penelitian Suatu Pendekatan Praktik. Jakarta;Rineka Cipta.

Arikunto, Suharsimi. (2013). Prosedur Penelitian Suatu Pendekatan Praktik. Jakarta; Rineka Cipta.

BSNP. (2006). Permendiknas RI No. 22 Tahun 2006 tentang Standar Isi 
untuk Satuan Pendidikan Dasar dan Menengah. Jakarta.

Depdiknas. (2006). Permendiknas No 22

Tahun 2006 Tentang Standar Isi.

Jakarta; Depdiknas.

Dian Noer Asyari. "Keefektifan Model Guided Discovery Learning untuk Menigkatkan Keterampilan Berfikir Kritis” Edupedia, 2019.

Direktorat Pembinaan SMA-Direktorat Jenderal Pendidikan Menengah. (2013). Panduan Pelaksanaan Pengimbasan Implementasi Kurikulum 2013 SMA. Jakarta: Direktorat Pembinaan SMADirektorat Jenderal Pendidikan Menengah.

Fadillah, M. (2014).Implementasi Kurikulum $2013 \quad$ Dalam Pembelajaran SD/MI, SD/MTS, dan SMA/MA. Yogyakarta; ArRuzz.

Gultom Syawal. (2013). Meteri Pelatihan Guru Implemantasi Kurikulum 2013. Jakarta; Badan pengembangan sumber daya manusia pendidikan dan kebudayaan.

Hamalik Oemar. (2015). Kurikulum dan Pembelajaran.Jakarta; Bumi Aksara.

Kunandar. (2014). Penilaian Autentik (Penilaian Hasil Belajar Peserta Didik Berdasarkan Kurikulum
2013) Edisi Revisi. Jakarta; PT Raja Grafindo Per-sada.

Moleong, Lexy. (2007). Metodologi Penelitian Kualitatif.Bandung; Remaja Rosdakarya.

Moleong, Lexy. (2011). Metodelogi Penelitian Kualitatif Edisi Revisi. Bandung; Remaja Rosdakarya.

Muhammad Nurtanto, Soffan Nurhaji, Dwi Widjanarko, M. Burhan R. Wijaya, Herminarto Sofyan. "Comparison of Scientific Literacy in Engine Tune-up Competencies through Guided Problem-Based Learning and Non-Integrated Problem-Based Learning in Vocational Education", Journal of Physics: Conference Series, 2018. Mulyasa, E. (2006). Kurikulum Tingkat Satuan Pendidikan. Bandung; Remaja Rosdakarya.

Mursida Aziz. "Efforts to Improve the Quality of Islamic Education Institutions in the Millennium Era", International Conference of Moslem Society, 2019.

Nana Sudjana. (2009). Penilaian Hasil Proses Belajar Mengajar. Bandung; PT Remaja Rosdakarya. Nur Samsiyah, Apri Kartika Sari, Chrisna Emilia. "Konstruksi Tes Kebahasaan UAS SD di Kabupaten Madiun”, Premiere Educandum: 
Jurnal Pendidikan Dasar dan Pembelajaran, 2016.

Nuril Annissa Ekayanti, Vitalis Djarot

Sumarwoto. "Peningkatan Sikap

Empati Melalui Bimbingan

Kelompok Berbantuan Teknik

Problem Solving Pada Siswa Kelas

X.A.V.1 SMK Negeri 1 Jiwan

Kabupaten Madiun”. Counsellia:

Jurnal Bimbingan dan Konseling,

2015.

Permendikbud (2016) Nomor 23 Tahun

2016 Tentang Standar Penilaian

Pendididkan.

Sugiyono. (2012). Metode Penelitian

Kuantitatif Kualitatif dan $R \& D$.

Bandung; Alfabeta.

Sugiono (2012).Memahami Penelitian

Kualitattif. Bandung; Alfabeta.

Sugiono. (2015). Metode Penelitian

Kombinasi (Mix Methods).

Bandung; Alfabeta.

Sumarno Sastro Slamet. "Hubungan

Strategi Umpan Balik (Feedback),

Motivasi Berprestasi dan Hasil

Belajar Dalam Pembelajaran

PPKn di SMK", PINUS: Jurnal

Penelitian Inovasi Pembelajaran, 2020.

Unais Mabruroh, Diah Sunarsih, Atikah

Mumpuni. "Analisis Kesulitan

Belajar Muatan Matematika Kelas

IV SD Tahfidzul Qur'an Darul
Abror", Jurnal Ilmiah Kontekstual, 2020.

Undang-Undang Dasar 1945.

Undang-Undang Nomor 20 Tahun 2003

Pasal 1, Ayat 19. 